\title{
Conservation Concept on Areas with Overlapping Character (Moslem, Colonial and Post-Independence Era)
}

\author{
R. Siti Rukayah, Bharoto, Abdul Malik \\ Architecture Departement, Engineering Faculty, University of Diponegoro, \\ JI. Prof. Soedharto,SH., Tembalang, Semarang, 50275, Indonesia \\ tututrsiti@yahoo.com
}

\begin{abstract}
Ancient maps reveal that Dutch colonial have covered alun-alun as the Moslem city image like those in Jakarta, Surabaya, except in Semarang. Both Indonesian Moslem and colonial city experts cannot explain the phenomena. The alun-alun lama Semarang left its morphologic artifacts. Which layer of urban design should be conserved? To reveal the layer of the development, three-dimensional picture by freehand modeling based on visual historical approach method can be done as an early stage. The civilization era are in interaction, but tend to neglect the Moslem city image. Further research is needed using a computer drawing, to get a clearly image of Moslem city.
\end{abstract}

Keywords: city's civilization era; conservation; urban pattern; morphology modelling

eISSN 2514-751X @ 2018. The Authors. Published for AMER ABRA cE-Bs by e-International Publishing House, Ltd., UK. This is an open-access article under the CC BY-NC-ND license (http://creativecommons.org/licenses/bync-nd/4.0/). Peer-review under responsibility of AMER (Association of Malaysian Environment-Behaviour Researchers), ABRA (Association of Behavioural Researchers on Asians) and $c E-B s$ (Centre for EnvironmentBehaviour Studies), Faculty of Architecture, Planning \& Surveying, Universiti Teknologi MARA, Malaysia.

https://doi.org/10.21834/aje-bs.v3i8.278 


\subsection{Introduction: Colonial and Moslem Character In Alun-Alun}

There are many architecture conservation and urban design experts in Indonesia, but most of them still oriented to the remaining of Dutch colonial. Roosmalen (2005) and Budihardjo (1997), mostly reveal the remaining of Dutch colonial in Indonesia.

It is widely known that architecture and city history in Indonesia have phases that begin with traditional remaining, the penetration of Islam civilization in 13-15th century, Dutch colonialism in 15th century, and then independence era in 1945. The Extended Dutch colonialism leaves behind a beautiful urban design in various cities. Most experts are only focusing on that era. They have not revealed that the layering of colonial civilization on the previous layer (Islam) or cities with Moslem's character. Cities with Moslem's character (in Java's northern coasts) are often researched by Moslem's city archeologist, such as Tjandrasasmita (2000) and Andrisijanti (2000). Characteristic of cities in Java northern coast have same pattern of alun-alun, in which there is mosque in the western side, governmental office in southern side, and market in northern or northern east side of it. There are speculations that this pattern oriented to city concept of Indonesian kingdoms, like Majapahit in 8th century, Mataram Islam in 13th century (cosmologist). However, Rukayah (2007) shows that the concept of Islam cities had driven away from its root in cosmological concept. Islam does not recognize "cosmic strength" or cosmic symbolization. It's assumed that the function of alun-alun in front of the mosque is an extension of the mosque's yard to contain more people and also as a yard for Keraton. The location of alun-alun was on the edge of traffic (river or sea) as waterfront concept.

In Semarang, the layer of development phase from the early era (Islam period), colonial era, to post independence era can be traced. Meanwhile Jakarta and Surabaya, as the large cities, have lost their former shape. Rukayah's (2010), stimulates an extended research that there was an effort from Dutch colonial to cover the characteristic of indigenous urban design. In semarang it is still traceable, it appears that the development of open spaced market into a permanent building by the Dutch colonial was in fact occupying some part of the alun-alun. This development is of course contradicting with the concept of conservation, that new developments were not supposed to tamper or to replace the priceless artifact from the past.

\subsection{Research Questions}

Referring to constitution no 5/1992 about Objects of Cultural Heritage, the conservation is a strain of action directed to restore the nature of objects of cultural heritage and to strengthen the structure if it is necessary. Then what about the case of alun-alun lama Semarang?

\subsection{Research Purpose}

The purpose of the research is to discover a layer of urban design development and to find area viewing unit that gives direction to the scope of historic city conservation.

\subsection{Benefit of the Research}

The findings are expected to enrich the historic city image as an input to the city 
government in regulating conservation.

\subsection{Literature Review: Theoretical Discussion}

\subsection{Historic City Conservation}

Referring to Lynch (1960), there is an area viewing unit that gives direction to the scope of historic city conservation (path, edges, district, node, and landmark). Different from Lynch, non-physical image of a city was stated by Rukayah (2010), formed by the existence of marketactivity in open space. In an international seminar in Bangkok, 2012, Rukayah stated that it is as a relationship between contain and container.

\subsection{The Transformation of Alun-alun}

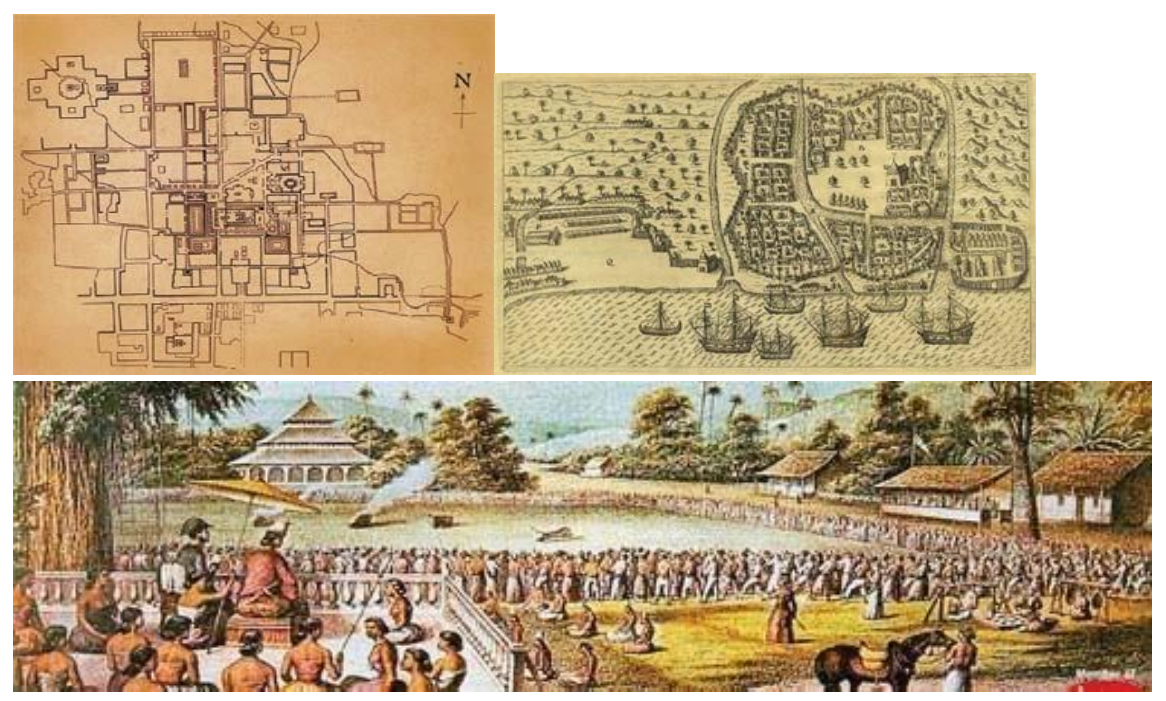

Fig.1. (a) Alun-alun in Majapahit Era. Source: Santoso,2008; (b) Alun-alun in Islamic era, Banten; source: www.swaen.comlantique-map. (c) Alun-alun, reconstruction of the philosophy of the sultanate have double role, as rule of goverment and religious.

(Source: Chromolithografie van C.W. Mieling naar L.H.W.M. de stuers, 1865. Collectie KITLV)

Some researchers like Tjandrasasmita, 2000; Rukayah, 2010, classify into several stages : Majapahit era (century 8), the era of Islam (century 13), Sukarno era (early 1970s) and the Modern era (after the penetration of modern retail in the 1970s). Alun-alun in the Majapahit era is known as the cosmic space. Alun-alun in Islamic era, no longer use the concept. During that time, sultanate as the ruler had double roles as a khalifatullah ing alaga sayyidin 
panatagama, that means that Sultan had a role as a leader of religion and government. The philosophy of Sultan's position is reconstructed in the design of the downtown, where Keraton (government central) and mosque (religion central) are located in alun-alun. Events held in alun-alun are controlled by the institution of Keraton and mosque. In the era of President Soekarno, He built a replica of the alun-alun, in Semarang city (1969s), to replace the loss of the alun-alun lama (in old Semarang city).

\subsection{Centres of Moslem cities in Indonesia}

Centers of Moslem cities in Java are marked by the existence of Keraton, mosques, and alun-alun as special traits of cities in the northern coast of Java, Tjandrasasmita (2000). Meanwhile Andrisijanti (2000), emphasizes at a concept of Islamic Sultanate city, is in the rural areas or throughout the Java Northern coast. Rukayah (2005), stated that the concept of Muslim city throughout the northern coast of Java strained away from Hindu's concept; alun-alun is neither a cosmic space nor a straight square.

\subsection{Colonial Cities in Indonesia}

Roosmalen, as a planner from the Netherlands had been concentrating in the developmentand the morphology of Java colonial cities and buildings. Several researchers about colonial buildings and their environments, like Budiharjo (1997), is more focused on the problem of Dutch colonial urban settlement and the remain of buildings of the colonialism. No one has yet to discuss that some of the city spaces designed by the colonialism are built on top of the crumbs of the concept of city made by indigenous people.

\subsection{Area with Overlapping Character}

From the discussion theory, it can be concluded that alun-alun in Moslem era is a downtown with character of Sultanate or Moslem city. When the Dutch colonial downtown then rose side by side or on top of it, then what kind of conservation concept should be implemented, up to now has yet to be touched by researchers.

\subsection{Methodology and Limitation of the Study}

It obviously needs a data-mining in the past, revealing the present data, even creating a model in each era to see how artifacts interact the image of the city. Thus, this research is done by mixing historical, naturalistic, and modelling (depicting city's morphology) method, or mix-method, Ridenour (2008).

To peal the historical layers of city development, according to Martin (2004), traditionally historicists focus only on written source as the main source and ignore the power of photographic source. Photos are often seen as the decoration of a text. I compare several ancient maps that show the spatial morphology in downtown Jakarta, Surabaya, and Semarang untill the uniqueness of Semarang was found. To historically analyze within the urban design according to Cliff (1999), the key for development in the future is to perceive 
the spirit of place, by pealing the historical phase up to being a modern city. Understanding why it happened is a key for future activities. The wealth of the real definition of urban is a product that is resulted from a long historical process of its city development.

Naturalistic method is used to obtain the present data. Researchers took the field without any theory. Modelling method using a three - dimensional picture of the area is used to obtain a three- dimensional meaning, Groat (2001). Computer modelling to have accurate image is indeed doable, but freehand modeling can also be done as an early stage.

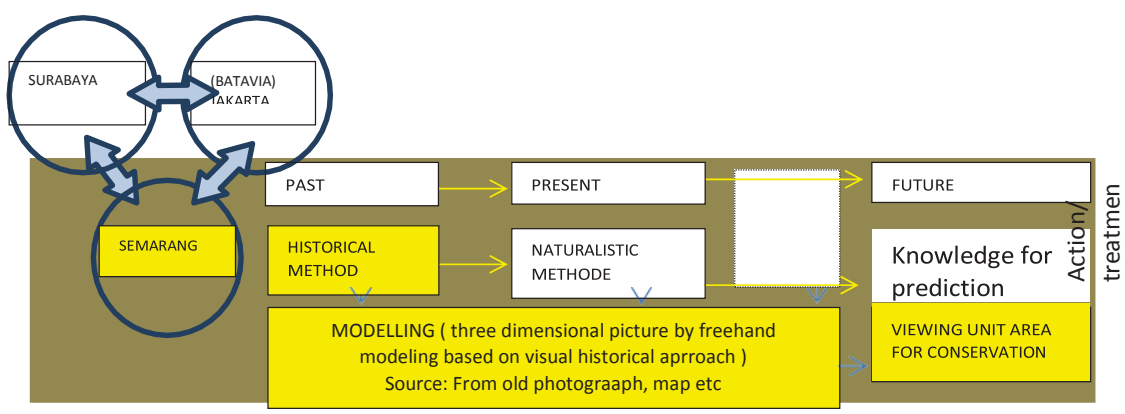

Fig.2.Mixed Methode.Three-dimensional picturebyfreehandmodeling based on visual historical and naturalistically approach method;

(Source: Reseacher's analysis, 2012).

\subsection{Results and Discussion}

\subsection{Downtown in Jakarta, Surabaya, and Semarang}

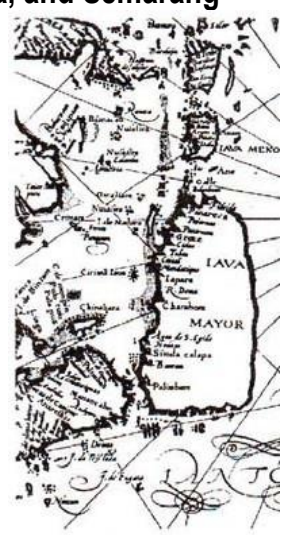

Fig . 3. East Indies 1596, Jakarta (Calapa), Surabaya (Churabhaya) and Semarang (Pragota) as the trading 
city in the northern coastal of Java, own a similar characteristic at the beginning of their developments, Moslem city;

(Source: Heuken, 1997).

The spreading process of Islam through trading path and marriage with noble class surfaced cities with Moslem character in Indonesia, mainly in Java. Downtown consists of alun-alun, Keraton or government central, mosque on the west side, market on the north side, close to the port (Tjandrasasmita, 2000). Jakarta (Calapa), Surabaya (Churabaya), and Semarang (Pragota) own a similar characteristic at the beginning of their developments. Jakarta and Surabaya will be discussed limited to give depiction of the former downtown. A more detailed explanation is directed to Semarang.

\subsubsection{Surabaya}




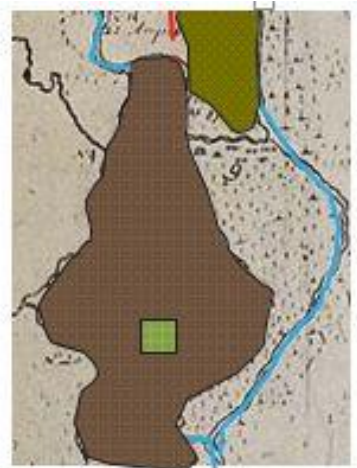

3. Map 1677 , reconstruction of Kcaten Surabaya's early years. Red is the approximate area of Kraton. Surabaya. Green is the aproximate alun-alua. Red line is the plan of Kalimas, tiver to be straight of for the future.

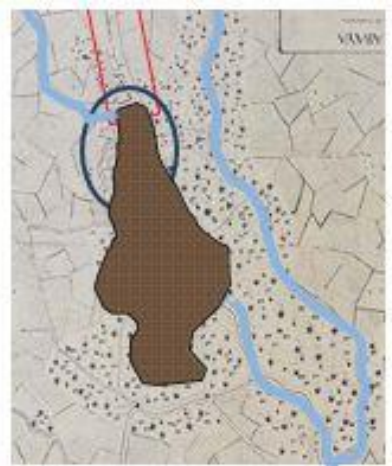

b. Surabaya Map 1787 , Kalimas is straightened, bluecircleis Dutch settlement

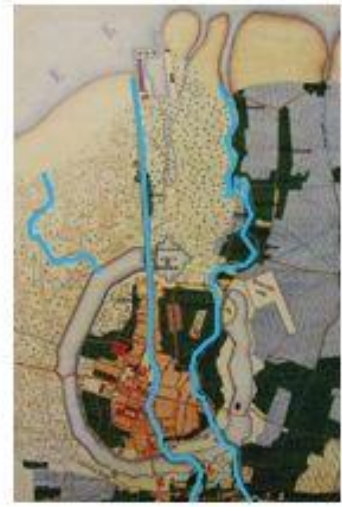

d. Surabaya map, 1867

c. Surabaya map, 1825

Fig. 4.Surabaya'smorphology, withdowntownasaKeratoncentralatfirst;

(Source: surabayatempodoloe.blogspot.coml)

According to the hypothesis of Von Faber, Surabaya was raised at $1275 \mathrm{M}$ by King Kertanegara as a new settlement for his soldiers that succeeded in eliminating Kemuruhan rebel at $1270 \mathrm{M}$. The pattern of city arrangement in Surabaya at early years is explained by Van Faber,1953). He believes that Surabaya is located northern of Glagah Arum with the border of Kalimas in the west and Pegirian River in the east. Because of the massive war in 1719, the heritage of the downtown was not brought down, Graff, 1986. (Handinoto 1996).

Depiction about Surabaya's early years, explained by Artus Gijsel by the knowledge about the structure of city space in Java. 
......The palaces is located in city area, approximately near the river, surrounded by large walls and inside were houses (like common Javanese Keraton). In front of the gate located an alun-alun with beautiful trimmed banyan tree. The market is located in front of the Keraton........

Agreeing with Gijsel, Valentyn, a Dutch sailor at year 1706, pictured :.......Surabaya is famous with 10000 house settlement under a power of a prince. Prince dwells inside a beautiful palace and owns a large beautiful cage for his elephants. He's often seen taking a walk... roads in the city are wide and the alun-alun, where war training is regularly held, is made very beautiful. Between the palace and the Dutch fort located a vast market ......

Their description can be found in Surabaya's first map, 1677. The map was used by Mataram's accomplices (VOC) to rule Trunojoyo in Surabaya Kraton. (image a).

In 1787 Kalimas river was straightened. The positioning of the fort is right at the northern side of indigenous settlement/ traditional downtown. In 1825, traditional downtown no longer appeared. Above the indigenous settlement was already built colonial downtown. In the map in 1867 Dutch government planned to surround Surabaya with expensive forting system, but the project was left unfinished.

\subsubsection{Jakarta}

According to Grijns, Nas (2007), Batavia was built in 1619 (Jayakarta). Dutchmen destroy the indigenous settlement and made Batavia. Agreeing with Grijns, Heuken (1997), stated that the destruction of indigenous downtown or Kraton Jayakarta was under the lead of JP Coen in 1619. Not even one building was left behind from Sunda Kelapa or Jayakarta, except for its name, Padrao stone, and probably Prince Jayakarta's tomb stone.

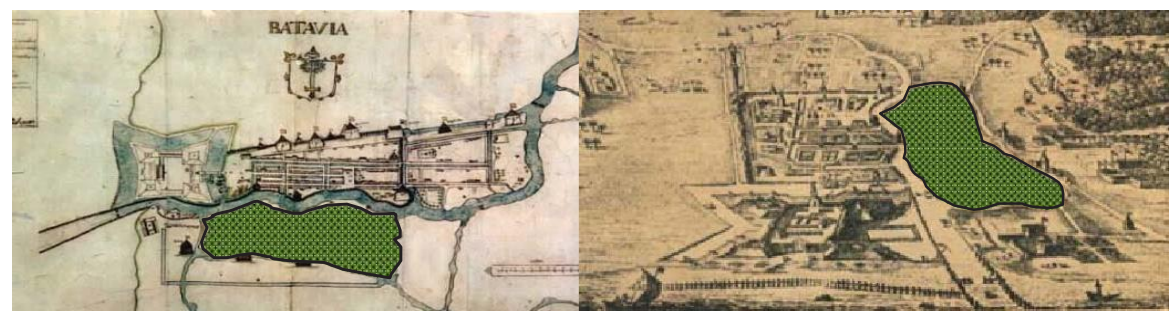

Fig. 5.(a)Batavia seen fromaerial view, 1629. (b)Bird'seyeview-Vogelvlucht. Keraton centeristhe aproximate in green colorarea. The colonial city was built ateastern of Keratoncenter, Ciliwung riverthathad notbeen straightened yet;

(Source:Heuken,1997; Reseacher'sanalysis, 2012; SketchofBataviamap(1628), showthattheDutchcolonialcity was builtatthe eastside of Keraton remaining) 

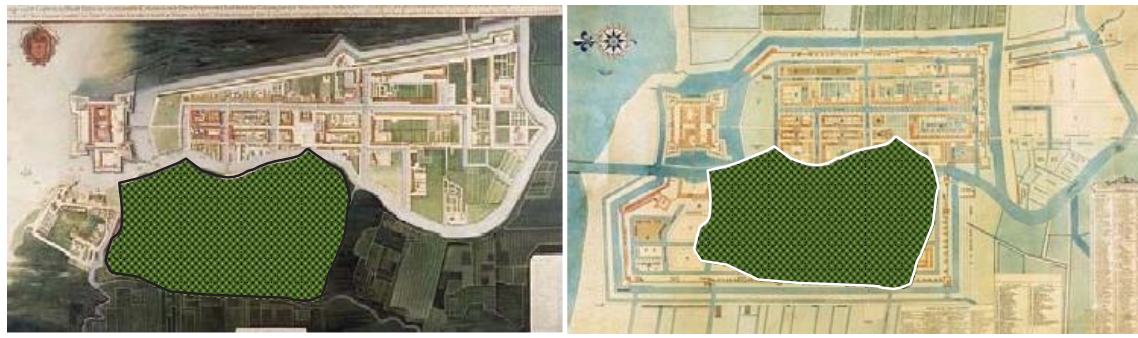

Fig6. (a)Batavia.1667, center ofurban settlement thatformerly stood on the east side of the river expanded to the western side, builton top of the Keraton remaining (green color).(b)Ciliwunghavebeenstraightened, the Dutch colonial setllement finally finished;

(Source: Heuken, 1997; BataviamapbuiltbyJPCoenalreadyshowedtheexpansion ofthecity, directed on top ofthe remaining of Keraton, Jayakarta)

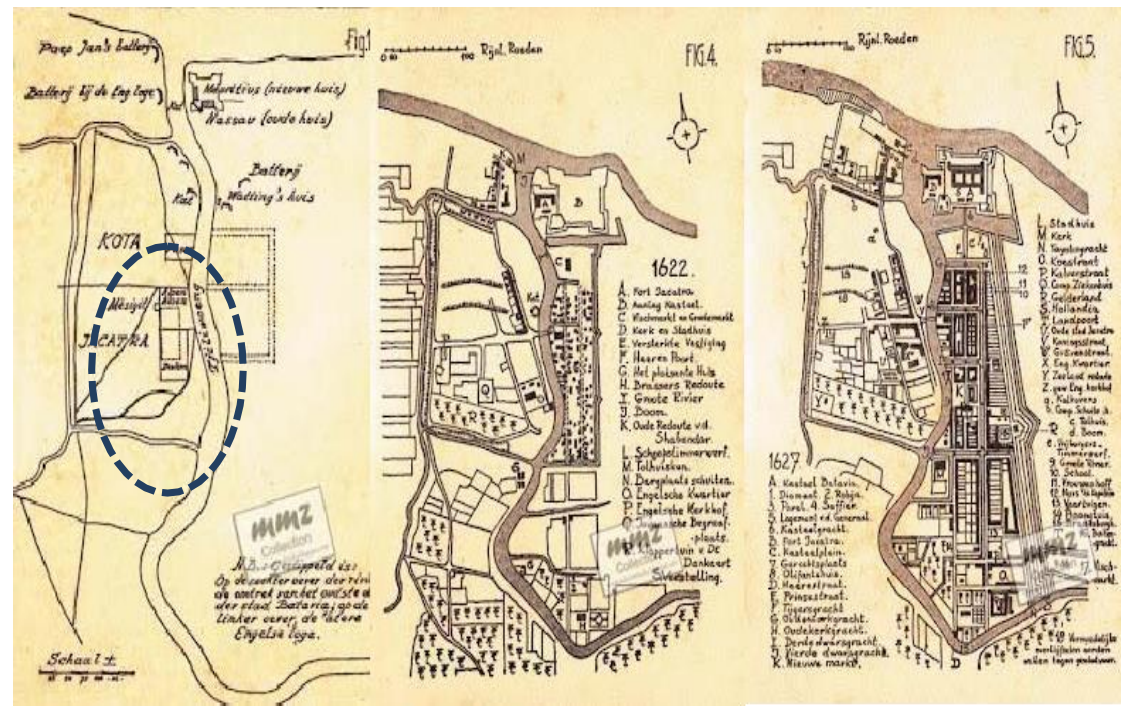

Fig7.(a)Reconstruction oftheKeraton Jayakarta'slocation. The downtown's structurewascomposedbyalunalun, mosqueonthewestern side, Dalemonthe easternside, andmarketonthenorthernside.

(b-c)itsdevelopment. Dutch Kasteel existed at 1619 according to JW lizerman; source: Heuken (1997), Tjandrasasmita, 2000, mmz collection.

\subsubsection{Semarang}

Different with the two previous cities where the old towns are gone, alun- alun lama Semarang is still itact. 


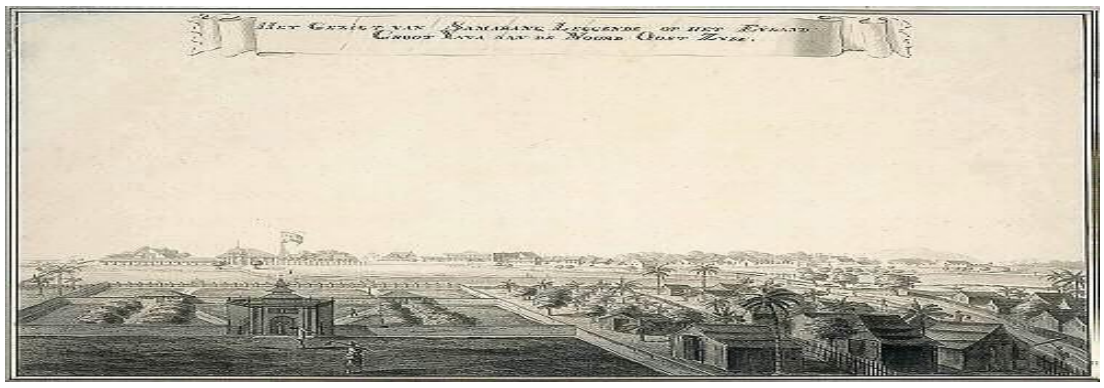

Fig 8. Center oftheold towninSemarang, Dalemandalun-alun with the colonial city as the background, painted by Johaness Racht(1857);

(Source: skyscrapercity.com)

\subsection{Structure and Composition of the Downtown}

Structure and composition of the former downtown Semarang were pictured clearly at the map of Semarang City Plan in 1695 (Plaan van het Fort en oleggende van Samarangh or Plan of Upper Fort and the Situation Looks Semarang). Javaanse Temple/Mosque was located western of Semarang river close to the Dalem/Indigenous Government Office. Southeastern of Dalem was a vast field/ paftee baan (paseban)/a place for "seba"/alun-alun. Location of the Pasjaars/Passaars of Mark Plaatsen or a yard where the new market activity was pictured at the map of Semarang City Plan year 1800 (Plaan of Platte Grond van Samarangh met dies Environs op een afstand or Plan / It looks from Upper Plains Semarang and surrounding environment). In 1705 , Semarang was officially surrendered by Mataram to Dutch. Since then the political authority of indigenous ruler disappeared. Semarang's development no longer followed the pattern/ traditional concept, as seen at map (Plan of Platte Grond van Samarangh met het Dies Environs op een Afstand).

\subsection{The Resistant Market Activity}

Market embryo in open space under the Johar tree in 1930 was planned to be a permanent building (Pasar Johar) that occupied eastern side part of the alun-alun. Alun-alun was no longer facing Kali Semarang directly. However, the number of merchants is increasing. in 1934, a part of western alun-alun was occupied as Pasar Yaik. Pasar Yaik and alun-alun in the night, was a recreation spot for citizens from all over Semarang. (1956, Published by Bakoenoen Semarang; Prana Agency Service,1953). In 1970s, modern retails were built around alun-alun. Pasar Yaik was made permanent in 1982. 


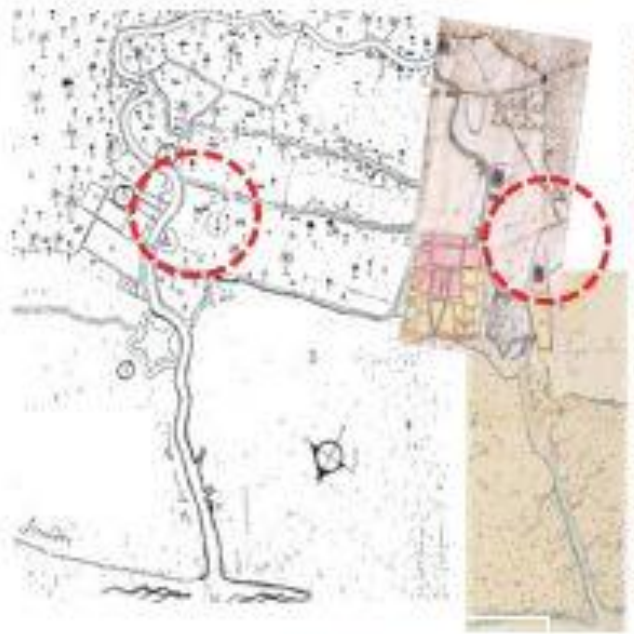

(2) Eerrerang (10:5), 1. Fort; 2 dastesenosed; 3 .

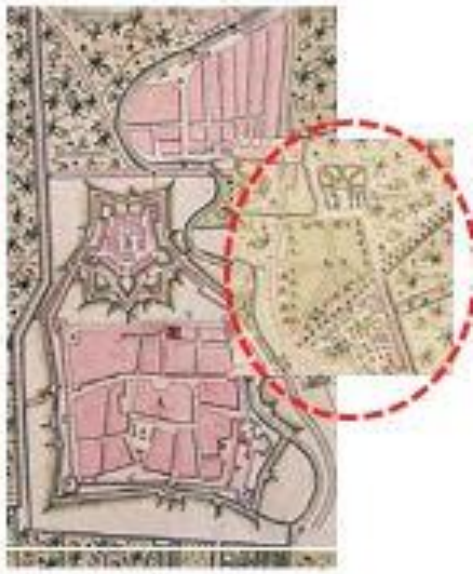

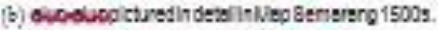

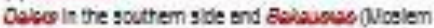

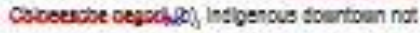

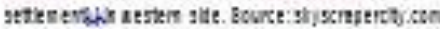

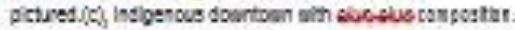

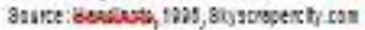

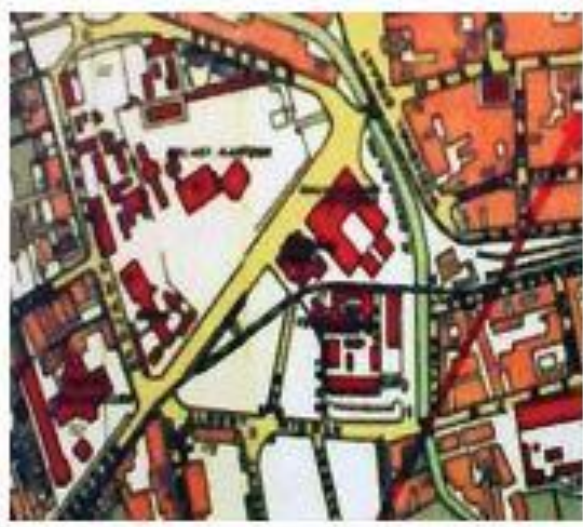

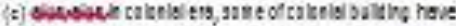
occupled in easterns te, facinglal Serrorang. Bowcei Boornar, 1005 .

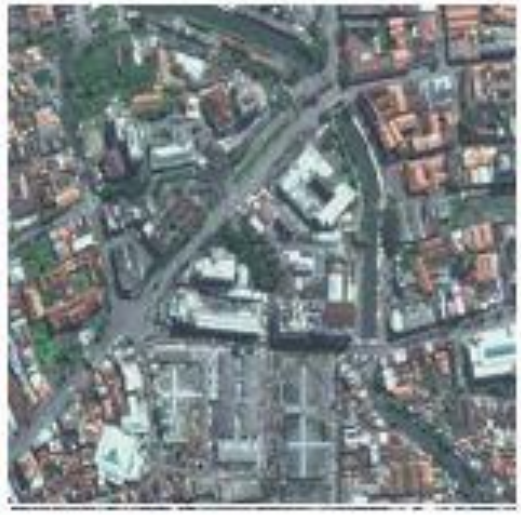

(d) pivaofing in googlems 2012 maxicut exintin

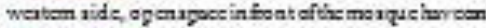
befichopefomthe maket ax a yad farmoxqueand geverpot offee The finction of yed ix ta cortain

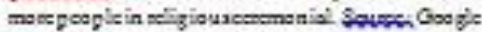
$\operatorname{mag} 2012$.

Fig9. The serial of Semarang mapthatbecome sourcesforthree-dimensional modelling; (Source:Handonoto, 1999; skyscrapercity.com; Boomer, 1995; google map, 2012) 


\subsection{Discussion Analysis}

To enhance the believability of the result that was found based on historic and naturalistic approaches; a modeling method is then used to obtain graphical explanation. By using ancient Semarang map, sketch/old photos, old aerial images, current aerial images, and ancient photos of buildings, the researcher tries to reconstruct the development phases of alun-alun lama Semarang. The three dimensional picture will given based on the modelling of the alun-alun lama development backward to the beginning.

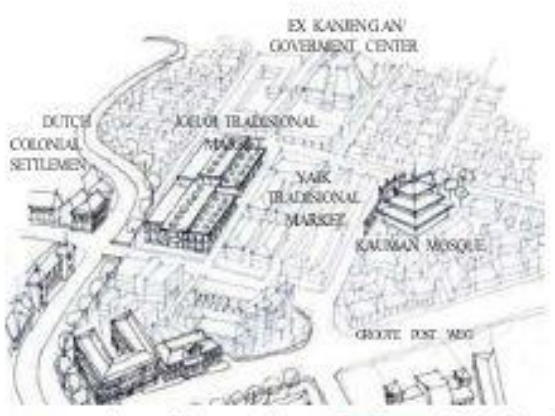

a casurty condition acouding to Soosklswes. 2012, figus in bold is hariage baikling from Duth coknial ea, exapt the

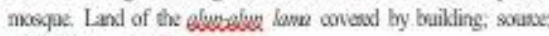
wacherc's analysi, 2012

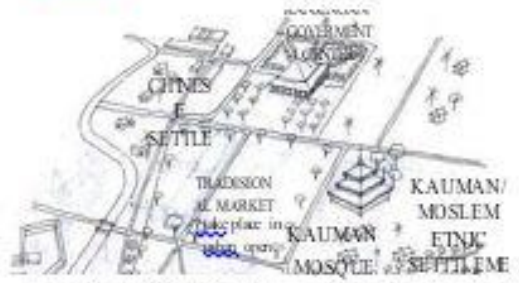

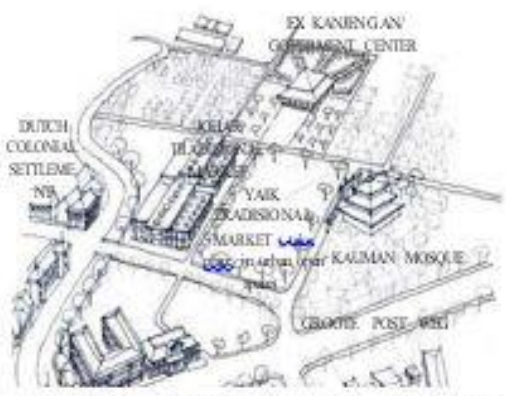

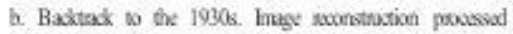
fom dea taken fiom Map of Somasng in 1719, 1800, sourc. swachex's analysis, 2012

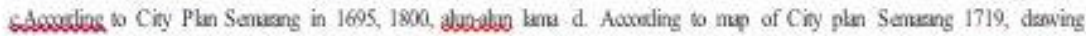

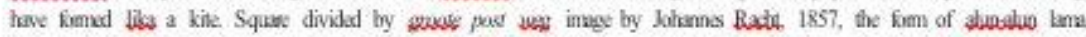

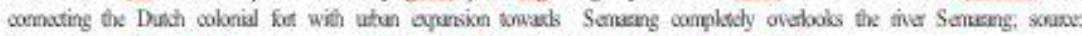

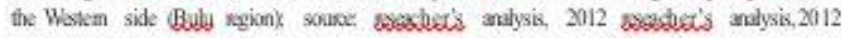

Fig.10. The serial three- dimensional image from the development of alun-alun lama Semarang, (Source: Researcher's analysis, 2012)

\subsubsection{From Traditional Space to Economic Space}

Dutch colonial moved the center of government from Jepara to Semarang at the eastern 
side of Kali Semarang, near the indigenous hometown and built a fort. Different from Jakarta and Surabaya, colonial government developed a city planning to Bulu district and here then built a new downtown (1700s) due to the population growth inside the fort. Between the fort and the new downtown was built a groote post that cut alun-alun into two parts. Along the side of the road grew colonial buildings. Even the embryo of traditional markets near Kali Semarang was made as a modern market, occupied some area eastern of alun-alun. As a result, alun-alun no longer faced kali Semarang. The characteristic of a perfect Moslem city along the Java's northern coast is now gone. Alun-alun was no longer an expanded space for the mosque but an economic space, and people's recreation center, mainly during the night. In the book of Trading and Tourist in 1956, it was predicted :

"...........it is highly possible that in the future alun-alun Semarang will be swallowed entirely for market........"

\subsubsection{The Conservation Design}

It is difficult to restore the shape of the square. The peal of a layer of urban design development from several eras found an area viewing unit that gives direction to the scope of historic city conservation. Themoslem era layer was left behind little open space of the square (now is occupied by the market Yaik) in front of the mosque. When we restore the part of area of the square to be a yard, the result is that the mosque becomes a land mark and the clearance of open space make the moslem visual character easy to be recognized. The next strategy is to restore the form and the function of Kanjengan as the center of government. In addition to function as the center of government, it will also serve to drive ceremonial and cultural event that still exists until today (dugderan: ceremonial event to facing fasting month/Ramadhan). Events from traditional market shoul be located in ground floor of the yard alun-alun lama and yard of Kanjengan.

\subsubsection{The Sustainable Design Space}

The effort of restoring alun-alun fully to its initial form is indeed difficult to do, as well as to diminish colonial building as constituted building/cultural heritage. However, there is an effort to restore the city image based on Lynch, 1960, that is to return the mosque as a landmark, to restore the alun-alun right in front of the mosque (it is still possible because Pasar Yaik does not have unique architectural character) to be an open space. Reconstructing the form of Kanjengan office by adding new functions and restores its yard. Elevating alun-alun to design the space below to contain the ex-merchants of Pasar Yaik and Kanjengan will then return the function of alun-alun to the yard of the mosque and Kanjengan. The elevation of alun-alun will be a visual boundary between rituals in the mosque and the secular activities in Pasar Johar. Image alun-alun as a Moslem city (Tjandrasasmita, 2000, Andrisijanti, 2000) is expected to reappear.

According to Rukayah 2012, giving container to merchants under alun-alun and the open space above is an effort to conserve market activity that has been done by local people and has been selected in the history of alun-alun's development. Thus the market will be the 
local character and the conservation effort does not only cover the physical artifacts but also cover the human activity that fills in the artifacts (contain and container).

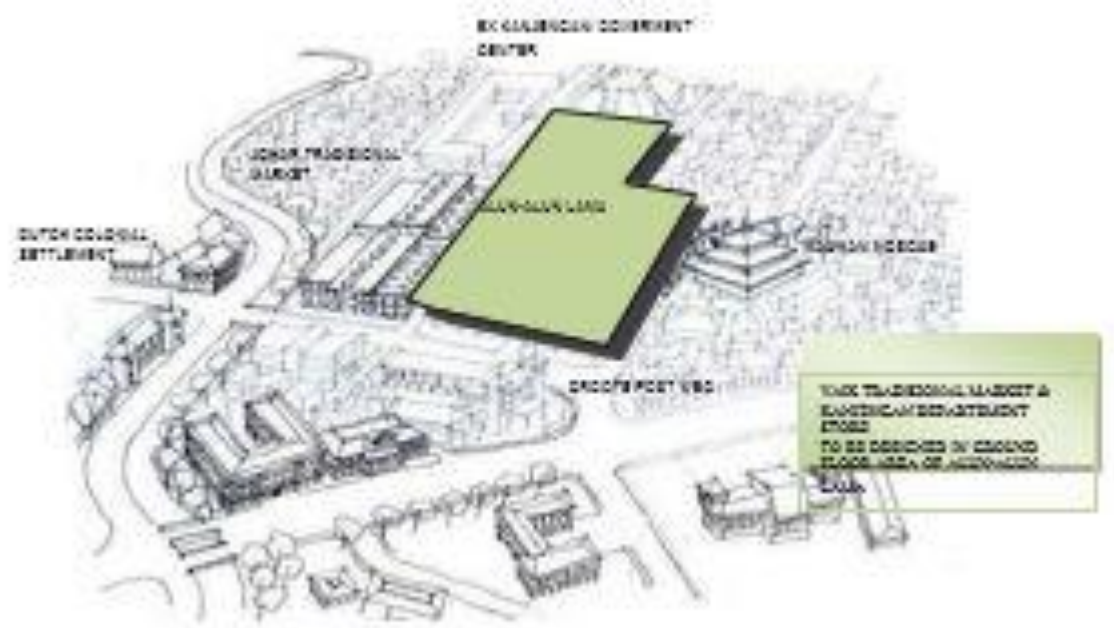

Fig 11. The concept of conservation design is to maintain the container and the contents ofthealun-alun lamaandtheconceptofsustainabledesignspacehistory between moslem and the colonial era; (Source: Researcher's analysis, 2012)

\subsection{Conclusion}

The effort of conservation container (alun-alun with moslem character) and contain (traditional market activities in urban open space) actually complementarry to constitution no 5/1992 about Objects of Cultural Heritage (The Republic of Indonesia Law. 1992). The conservation is a strain of action directed to restore the nature of objects of cultural heritage and to strengthen the structure of Moslem character with mosque and alun- alun as a landmark. In the case of alun-alun lama the conservation efforts still can be done. The mosque that still exists up to nowdays. Religious ceremonies welcoming the month of Ramadhan (fasting for Muslims) are still on going. Traditional market activity is increasing, and even leading to collapse modern retail. Thus, refering to the Lynch (1960), image as a city of muslims is stronger than colonial image. Only to focuse on efforts to conserve works of Thomas Karsten (Johar market) is very dangerous, because it will eliminate the actual image.

The findings of conservation in contain and container complete the conservation knowledge that have been focusing on the activities of physical artifacts. The activity of local people that has been attached in requires efforts that is equal to the life of the space.

Connection of contain and container from market activity to the artifacts of Moslem 58 
downtown predicts that market activity cannot be taken away from its container, nor changed into modern retail. The finding of conservation concept of continuous historical space can be generalized in other place with similar case.

\subsection{Recommendation}

This research has contribution to the conservation efforts for countries with protection needs to historical artifacts (Netherlands and Islam countries).

To conduct conservation, it is not only on the physicality but also on the filler, it gives direction to the decision makers and local government not to change traditional market into modern retails.

This research results in extended research question which is; how to conserve alun-alun as traditional character of Java cities. Using a computer drawing, to get a clearly image of moslem city is needed in further research.

\section{Acknowledgement}

For the completion of this research, author thanks to Allah SWT and thank to: Local Planning Goverment Semarang (Badan Perencana Daerah/ Bapeda Semarang) for the support of data about some of map Semarang. Local Archive Goverment Semarang, to their support about some serial map and photograph of old Semarang.

\section{References}

Anonym. (1956). Buku Petunjuk Alamat Dagang dan Touris Djawa Tengah. Semarang: Penerbit Bakoenoen.

Adrisijanti, I. (2000). Arkeologi Perkotaan Mataram Islam. Yogyakarta: Penerbit Jendela.

Budihardjo, E. (1997). PreservationAnd Conservation of Cultural Heritage In Indonesia. Yogyakarta: Gadjah Mada Unneversity Press.

Cliff, Moughtin , Cuesta, R., Sarris, C,. \& Signoretta, P. (1999). Urban Design Method and Technique. Architectural Press, A division of reed educational and professional publishing Itd. A member of the reed elsevier plc group.

Groat, L. (2001).Architectural Research Methods. New York: John Willey \& Son, Inc.

Handinoto. (1996). Perkembangan Kota dan Arsitektur Kolonial Belanda di Surabaya 1870-1940. Yogyakarta: Penerbit Andi.

Heuken S.J., A. (1997). Tempat-Tempat Bersejarah di Jakarta. Jakarta: Yayasan Cipta Loka Caraka.

Lynch, K. (1960). The Image of the City. Cambridge MA: MIT Press.

Martin, J. \& Martin, R. (Ed.). ( 2004). Every Picture Tells AStory. Seeing is believing? Approaches to Visual 
Research. Leicester: University of Leicester.

Roosmalen, P. (2005), Expanding Grounds, The Roots os spatial Planning in Indonesia. In F. Colombijn, M. Barwegen, P.Basundoro, and J.A. Khusairi(Eds.), KotaLamaKotaBaru;Sejarah Kota-Kota di Indonesia. Yogyakarta. Ombak

Rukayah. (2010). Simbiosis di ruang Terbuka Kota Simpang Lima Sema- rang. Unpublished undergraduated dissertation. Universitas Dipon- egoro.

Rukayah, Bharoto. (2012). Bazaar In Urban Open Space As Contain And Container Case study : alun-alun lama and Simpang Lima Semarang, Central Java, Indonesia. Mohamed Yusoff Abbas, Anniz Fazli Ibrahim Bajunid, Nik Farhanah Nik Azhari (Eds.). Proceeding, AcE-Bs 2012Bangkok @ASEAN Conference on Environment-Behav- iour Studies Siam City Hotel, Bangkok, Thailand, 16-18 July2012. Way of Life: Socio-economic \& CulturalContext.

Santoso, Jo. (2008). Arsitektur Kota Jawa Kosmos, Kultur dan Kuasa. Cen- tropolis.

Tjandrasasmita, U. (2000). Pertumbuhan dan Perkembangan Kota-ko- ta Muslim di Indonesia dari Abad XII sampai XVIII Masehi. Kudus: Penerbit Menara Kudus.

The Republic of Indonesia Law. (1992). No.5/1992 regarding Cultural Her- itage (povisional Translation) 